\title{
MASTER \\ Western Gas Sands Project Quarterly Basin Activities Report
}

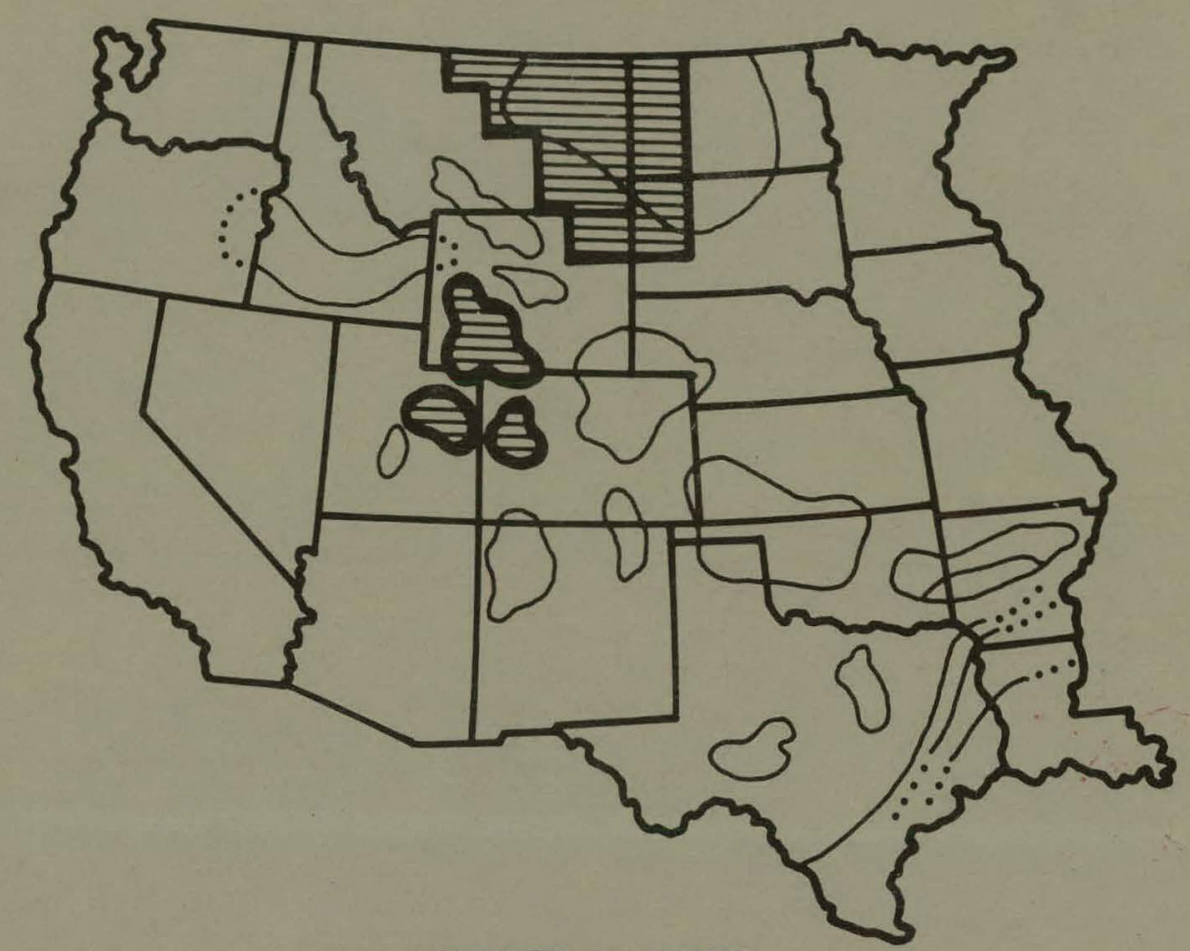

APRIL 1, 1978

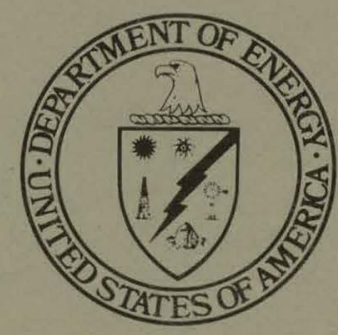

Prepared for

U.S. Department of Energy

Bartlesville Energy Research Center

Charles $\mathrm{H}$. Atkinson

Project Manager

Compiled by CER Corporation

Las Vegas, Nevada

Contract EY-76-C-08-0655 


\section{DISCLAIMER}

This report was prepared as an account of work sponsored by an agency of the United States Government. Neither the United States Government nor any agency Thereof, nor any of their employees, makes any warranty, express or implied, or assumes any legal liability or responsibility for the accuracy, completeness, or usefulness of any information, apparatus, product, or process disclosed, or represents that its use would not infringe privately owned rights. Reference herein to any specific commercial product, process, or service by trade name, trademark, manufacturer, or otherwise does not necessarily constitute or imply its endorsement, recommendation, or favoring by the United States Government or any agency thereof. The views and opinions of authors expressed herein do not necessarily state or reflect those of the United States Government or any agency thereof. 


\section{DISCLAIMER}

Portions of this document may be illegible in electronic image products. Images are produced from the best available original document. 
This report was prepared as an account of work sponsored by the United States Government. Neither the United States nor the United States DOE, nor any of their employees, nor any of their contractors, subcontractors, or their employees, makes any warranty, express or implied, or assumes any legal liability or responsibility for the accuracy, completeness, or usefulness of any information, apparatus, product or process disclosed, or represents that its use would not infringe privately owned rights.

Available from the National Technical Information Service, U.S. Department of Commerce, Springfield, Virginia 22161.

\begin{tabular}{|c|c|c|c|c|c|c|c|c|c|c|c|}
\hline \multirow[b]{2}{*}{$\begin{array}{l}\text { Page } \\
\text { range }\end{array}$} & \multicolumn{11}{|c|}{$\begin{array}{l}\text { NATIONAL TECHNICAL. INFORMATION SERVICE PAPER COPY PRICES } \\
\text { EFFECTIVE JAN. } 1,1976\end{array}$} \\
\hline & $\begin{array}{c}\text { Domestic } \\
\text { price }\end{array}$ & $\begin{array}{l}\text { Page } \\
\text { range }\end{array}$ & $\begin{array}{l}\text { Domestic } \\
\text { price }\end{array}$ & $\begin{array}{l}\text { Page } \\
\text { range }\end{array}$ & $\begin{array}{c}\text { Domestic } \\
\text { price }\end{array}$ & $\begin{array}{l}\text { Page } \\
\text { range }\end{array}$ & $\begin{array}{c}\text { Domestic } \\
\text { price }\end{array}$ & $\begin{array}{l}\text { Page } \\
\text { range }\end{array}$ & $\begin{array}{c}\text { Domestic } \\
\text { price }\end{array}$ & $\begin{array}{l}\text { Page } \\
\text { range }\end{array}$ & $\begin{array}{c}\text { Domestic } \\
\text { price }\end{array}$ \\
\hline 001.025 & $\$ 3.50$ & 126.150 & $\$ 6.00$ & 251.275 & $\$ 9.00$ & $376-400$ & $\$ 10.75$ & 501.525 & $\$ 12.75$ & $701 \cdot 800$ & $\$ 18.75$ \\
\hline 026.050 & $\$ 4.00$ & $151-175$ & $\$ 6.75$ & $276-300$ & $\$ 9.25$ & 401.425 & $\$ 11.00$ & $526-550$ & $\$ 13.00$ & $801 \cdot 900$ & $\$ 21.25$ \\
\hline $051-075$ & $\$ 4.50$ & $176-200$ & $\$ 7.50$ & 301.325 & $\$ 9.75$ & $426-450$ & $\$ 11.75$ & 551.575 & $\$ 13.50$ & 901.1000 & $\$ 23.75$ \\
\hline $076 \cdot 100$ & $\$ 5.00$ & 201-225 & $\$ 7.75$ & $326-350$ & $\$ 10.00$ & 451.475 & $\$ 12.00$ & $576: 600$ & $\$ 13.75$ & $1001 \cdot 1100$ & $\$ 28.25$ \\
\hline $101-125$ & $\$ 5.50$ & $226-250$ & $\$ 8.00$ & $351-375$ & $\$ 10.50$ & $476-500$ & $\$ 12.50$ & 601.700 & $\$ 16.25$ & $1101-1200$ & $\$ 32.75$ \\
\hline
\end{tabular}

For additional pages, add $\$ 4,50$ for each beginning 100 pages. Add $\$ 2.50$ per copy for foreign price.

Microfiche $\$ 3.00$ (domestic) $\$ 4.50$ (foreign).
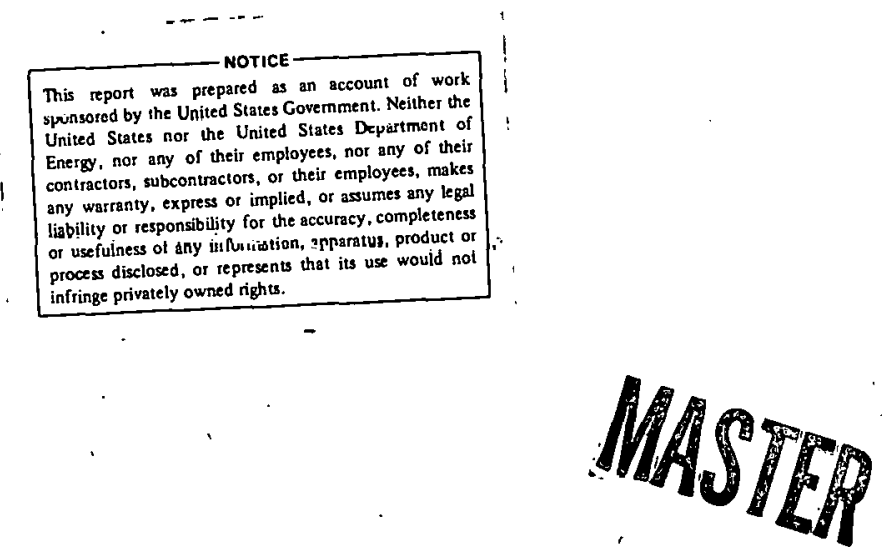

1. 


\section{CONTENTS}

$\underline{\text { Page }}$

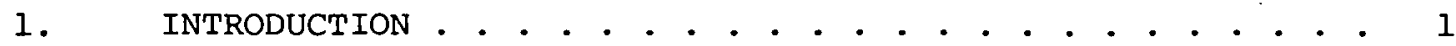

2. NORTHERN GREAT PLAINS PROVINCE . . . . . . . . . . . 3

2.1 Core Program .................. 3

2.2 Basin Activity . . . . . . . . . . . . 6

3. GREATER GREEN RIVER BASIN .................. . . ll

3:1 Core Program . . . . . . . . . . . . . . 11

3.2 Basin Activity . . . . . . . . . . . . . 11

4. UINTA BASIN . . . . . . . . . . . . . . . . . 19

4.1 Core Program . . . . . . . . . . . . . . . . . 19

4.2 Basin Activity . . . . . . . . . . . . . 19

5. PICEANCE BASIN . . . . . . . . . . . . . . . 25

5.1 Core Program . . . . . . . . . . . . . 25

5.2 Basin Activity .. . . . . . . . . . . 25 


\section{FIGURES}

Page

FIGURE 1-1 MAP OF WESTERN UNITED STATES, SHOWING AREAS OF INTEREST . . . . . . . . . . . . . . . 2

FIGURE 2-1 USGS DESIGNATED CORE AREAS, NORTHERN GREAT PLAINS PROVINCE . . . . . . . . . . . . . . . 4

FIGURE 2-2 USGS DESIGNATED CORE AREAS, NORTHERN GREAT PLAINS PROVINCE . . . . . . . . . . . . . . 5

FIGURE 2-3 NORTHERN GREAT PLAINS PROVINCE SHOWING WELLS OF INTEREST . . . . . . . . . . . . . . . 7

FIGURE 3-1 USGS DESIGNATED CORE AREAS, GREATER GREEN RIVER BASIN . . . . . . . . . . . . . . 12

FIGURE 3-2 GREATER GREEN RIVER BASIN SHOWING WELLS OF INTEREST . . . . . . . . . . . . . 14

FIGURE 4-I USGS DESIGNATED AREAS, UINTA BASIN . . . . . . . . 20

FIGURE 4-2 UINTA BASIN SHOWING WELLS OF INTEREST . . . . . . . 21

FIGURE 5-1 USGS DESIGNATED CORE AREAS, PICEANCE BASIN . . . . 26

FIGURE 5-2 PICEANCE BASIN SHOWING WELLS OF INTEREST . . . . . 28

\section{TABLES}

TABLE 2-1 INFORMATION ON WELLS IN THE NORTHERN GKEAT PLAINS PROVINCE . . . . . . . . . . . . . . . 8

TABLE 3-1 INFORMATION ON WELLS IN THE GREATER GREEN RIVER BASIN . . . . . . . . . . . . . . . . 15

TABLE 4-1 INFORMATION ON WELLS IN THE UINTA BASIN • • • • • $\quad 22$

TABLE 5-1 INFORMATION ON WELLS IN THE PICEANCE BASIN • • • • 29 


\section{INTRODUCTION}

This quarterly basin activity report is a summation of the coring program site identification and drilling and testing activity in the four primary study areas of the Western'Gas Sands Project (WGSP). Pertinent information for January, February and March, 1978 is included for each study area. The areas, shown on Figure 1-1, are the Northern Great Plains Province, the Greater Green River Basin, the Piceance Basin and the Uinta Basin. Additional marginally productive areas, indicated on the map, are not currently being reviewed in this report.

The WGSP Coring Program will aid resource assessment and reservoir analysis work for the evaluation of gas production potential from the western basins. The U.S. Geological Survey (USGS) is doing the majority of this resource assessment work and has had the lead role in identification of the core sites. To obtain the cores, associated well logs, test data, etc., in the areas of interest, the Department of Energy (DOE) will negotiate cooperative agreements and/or contracts with interested companies.

Geologic information relating to the four basins can be obtained from the Quarterly Basin Activities Report, January 1, 1978, NVO/0655-03. The report contains stratigraphic correlation charts, cross sections and a brief account of the geology for each area.

The drilling information used in this report was obtained primarily from The Rocky Mountain Region Report published by Petroleum Information Corporation on a daily basis. Additional information sources include the Montana Oil and Gas Journal and The Oil and Gas Journal both released weekly. 


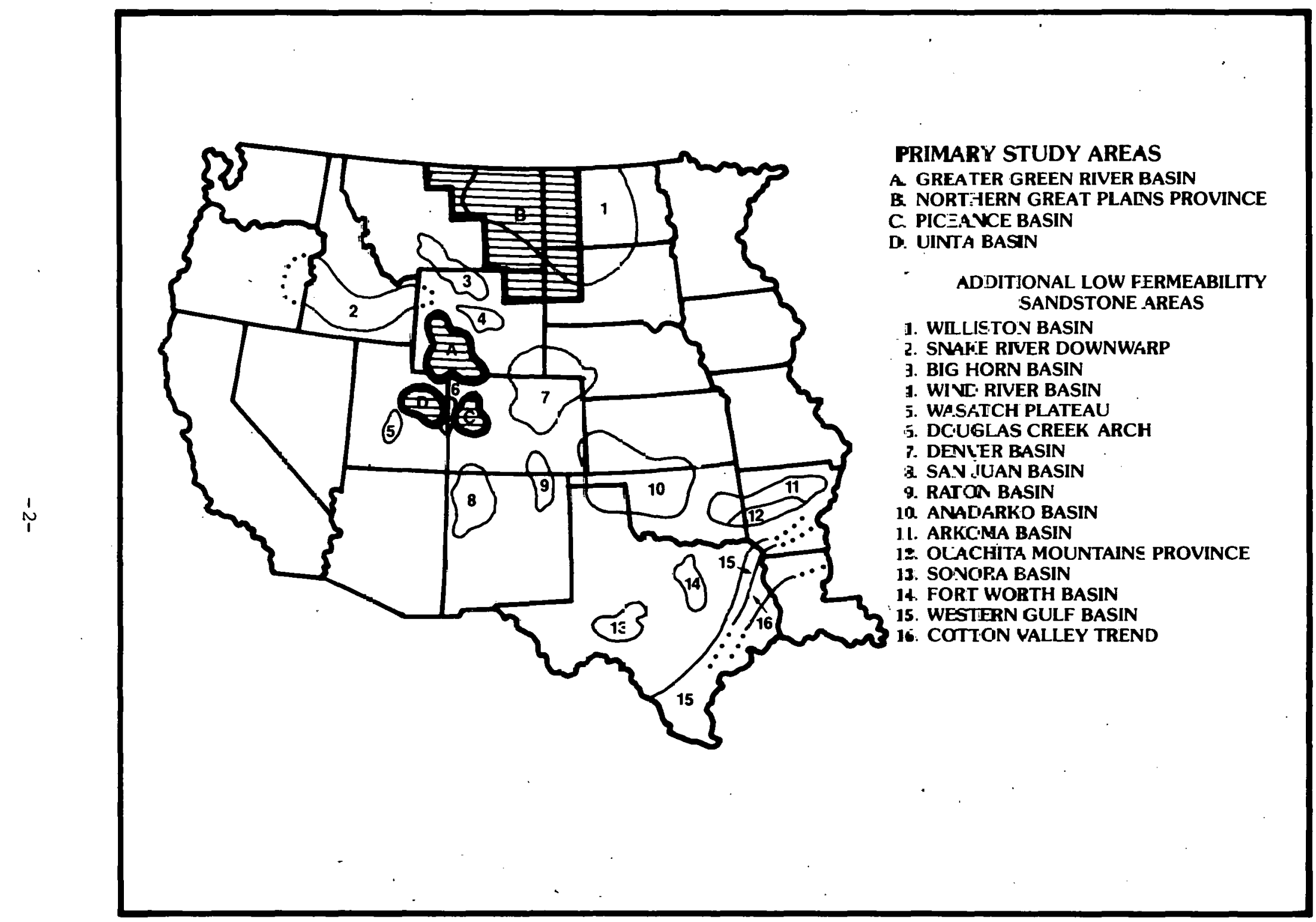

FIGURE 1-1 MAP OF WESTERN UNITED STATES, SHOWING AREAS OF INTEREST 


\section{NORTHERN GREAT PLAINS PROVINCE}

\subsection{Core Program}

The USGS has delineated a large area of Montana, northeastern Wyoming, and western North and South Dakota as having tight gas potential. This area is called the Northern Great Plains Province and comprises an area of about 125,000 square miles (Figure 2-1). The western boundary is based on the cropping out of potentially productive Upper Cretaceous units or where these units have developed into porous and permeable shoreline sandstones. The northern boundary is on the Canadian border and the southern boundary is along the north end of the Powder River Basin. South of this boundary the units are too deep for significant biogenic gas accumulations. The eastern boundary is based on the eastern limit of tight clastic reservoirs in the Upper Cretaceous units. However, there are chalks in the Upper Cretaceous Niobrara, Carlile and Greenhorn units in the eastern part of the province. These chalks have high porosities but low permeabilities and are considered to have excellent shallow gas potential. The eastern boundary of the province probably will be extended well beyond the present location when the extent of the chalks becomes known.

The USGS has chosen four core sites in the Montana segment of this Province to evaluate the Upper Cretaceous section (see Figure 2-2). Specific formations in each site are included along with the approximate coring intervals needed to effectively evaluate each location.

1. Powder River County

T5S, R52 and 53E

Judith River $200 \mathrm{ft}$

Eagle $400 \mathrm{ft}$

Niobrara (chalk) $200 \mathrm{ft}$

2. Custer and Prairie Counties

$\mathrm{T} 10$ and $11 \mathrm{~N}$, R48 and $49 \mathrm{E}$

Judith River $200 \mathrm{ft}$

Eagle $400 \mathrm{ft}$

3. Valley County (fractured reservoir)

T29N and $30 \mathrm{~N}, \mathrm{R} 35,36$ and $37 \mathrm{E}$

Eagle through Upper Mowry 1,450 ft

4. Phillips County

T29 and 30N, R26 and 27E

Eagle through Upper Mowry 1,400 ft 


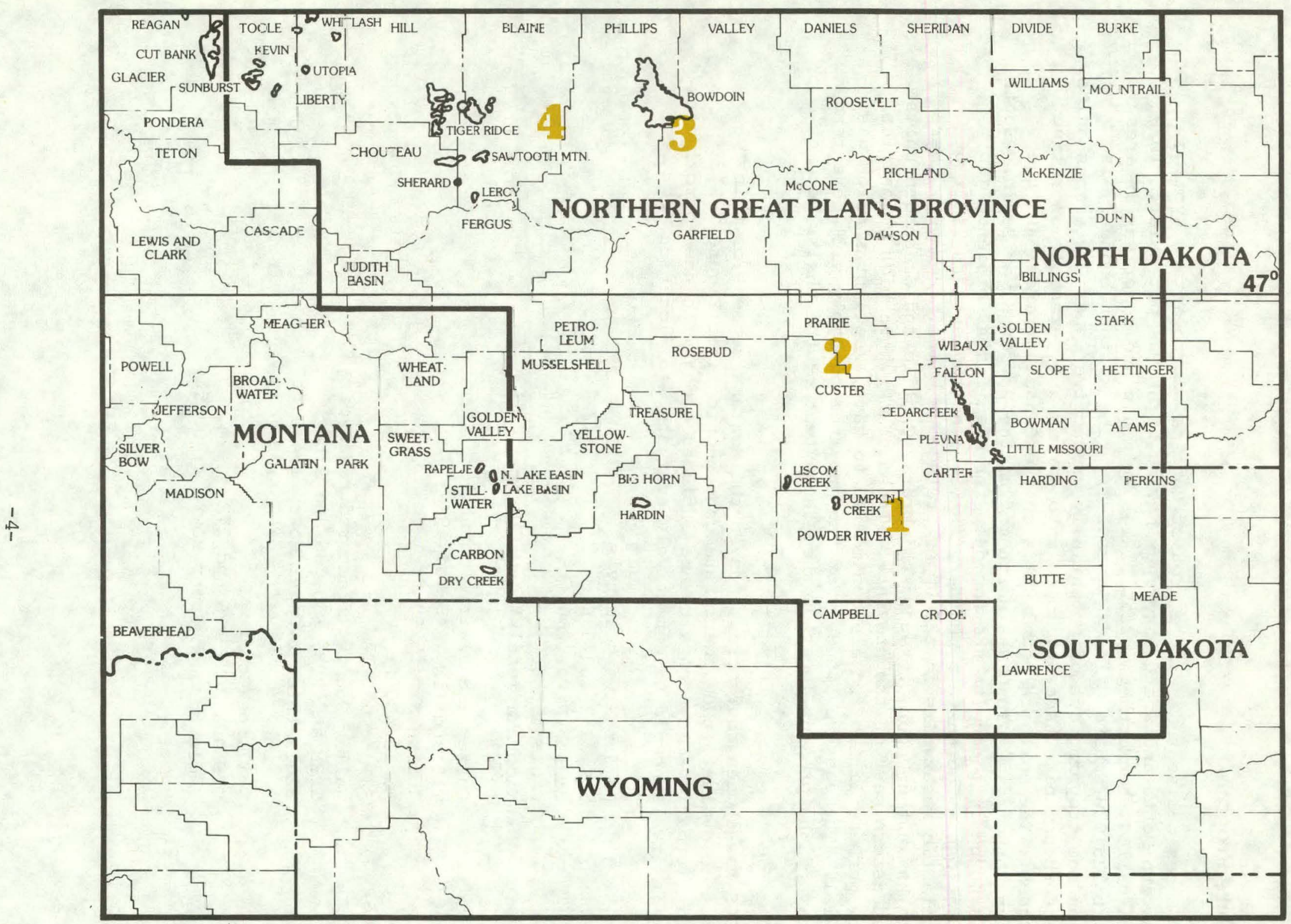

FIGURE 2-1 USGS DESIGNATED CORE AREAS, NORTHERN GREAT PLAINS PROVINCE 


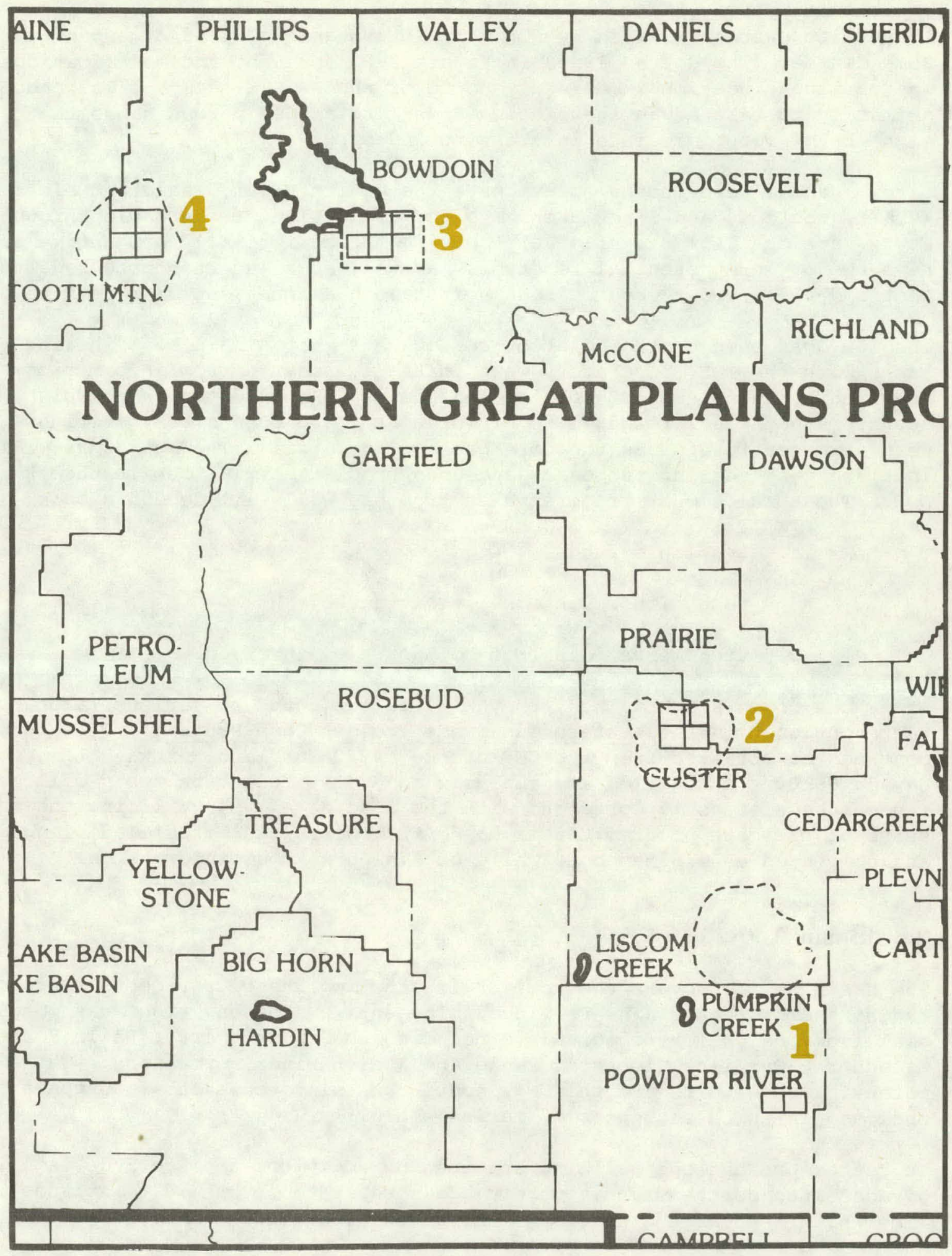

FIGURE 2-2 USGS DESIGNATED CORE AREAS, NORTHERN GREAT PLAINS PROVINCE 
These sites were evaluated by DOE contractors and modified or expanded to some degree. The dotted lines in Figure 2-2 represent the modifications. The outlined location immediately north of the USGS Site No. 1 was chosen primarily to take advantage of some Upper Cretaceous porous sands that might be of more immediate interest to industry.

Sites 1 and 2 were chosen to evaluate the Judith River, Eaqle and Niohrara (Challs) secliuls dnd sites 3 and 4 offer evaluation of the Eagle through Mowry section. All the sites are outside the commercially productive area, have two or more potential reservoirs as well as adjacent source beds to test and there are fractured reservoirs along a lineament zone at site 3 .

Industry has been contacted about coring these sites on a cost sharing basis with the DOE. Operators were initially losater from information supp $\perp$ ed by Petroleum Information lease maps. After detormining which operators had plans for drilling in or near these core sites, meetings were arranged to discuss the core package in detail. Tho opcrators will Initiate cost sharing proposals and upon completion will submit them to DOE. The total amount of core taken from one well will depend upon:
a. available funds,
b. ease with which core is extracted, and
c. recommendations from both parties involved.

After the cores are obtained, they will be subjected to various laboratory tests outlined in the Western Gas Sands Project Core Program. This document can be obtained from the CER office, 4220 Maryland Parkway, Las Vegas, Nevada 89109. A detailed log analysis and some production tests will be run on these sites to correlate with the core data. By utilizing the sesults of the core program, it is hoped that wells can be drilled, logged and completed at minimum cost while obtaining maximum information.

\subsection{Basin Activity}

The basin review covers the activity in the important Cretaceous sands of the Northern Great Plains Prnvince. The ontire area has Liylil yds potential from one or more intervals, including the Muddy, Mowry, Belle Fourche, Greenhorn, Carlile, Ninhrara, Eaglo and Judith Rives Furlldtlons. I'hese potential reservoirs are thin, discontinuous siltstoncs and sandstones enclosed in thick sequences of marine shale.

To better present the drilling and testing activity, the Province is divided into northern and southern areas separated by the $47^{\circ}$ latitude line which is near the northern part of the Cedar Creek Anticline. 


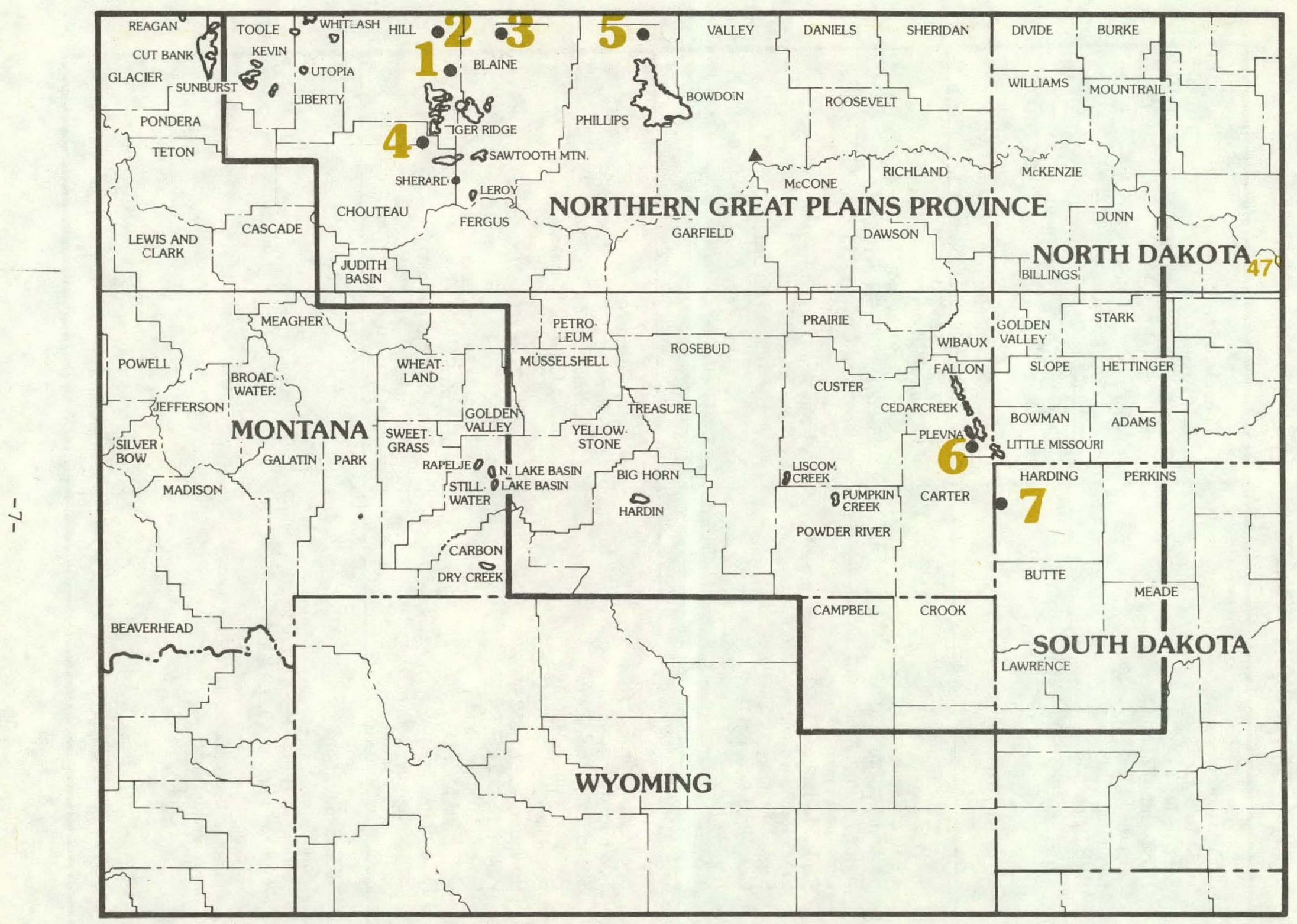

FIGURE 2-3 NORTHERN GREAT PLAINS PROVINCE SHOWING WELLS OF INTEREST 
TABLE 2-1 INFORMATION ON WELLS IN THE NORTHERN GREAT PLAINS PROVINCE

1. J. Burns Brown

14-33-16 State

Section 14, T33N, R16E

Hill County, Montana

Unnamed Field

Eagle test $(1,650 \mathrm{ft}$.

Wildcat outpost

Status: Waiting on cement

3. John S. Lyon

2 Batlle Creek

Section 14, T36N, R20E

Blaine County, Montana

Unnamed Field

Eagle Production (1,903-1,945 ft. gross)

Frac: 18,606 gal water, $4,000 \mathrm{lb}$. sand

Eagle Discovery-New Field

Completion date: $3 / 9 / 78$
2. Polumbus Petroleum

3-10 Knapp

Section 3, T36N, R13E

Hill County, Munilana

Wildcat

2nd White Specks test (2,500 ft.)

New field wildcat

Status: Waiting on cement

4. J. Burns Brnum

12-29-14 Rocky Boy

Section 12, T29N, R14E

Chouteau County, Montana

Unnamed Field

Eagle test $(2,000 \mathrm{ft}$.)

Development

Status: Waiting on orders
5. Shenandoah Oil Corporation

1-24 Federal

Section 24, T36N, R31L

Phillips County, Montana

Bowdoin Field

Bowdoin (1,287-1,352 ft.)

Phillips (1,452-1,517 ft.)

Frac: $82,000 \mathrm{lb}$. sand

IPF: 1,500 MCFD

Development gas well

Completion date: $2 / 23 / 78$
6. Pacer Resources

11-36 State

Section 36, T5N, R60E

Fallon County, Montana

Cedar Creek Field

Judith River (888-976 ft. gross)

Eagle (1,434-1,510 ft. gross)

Frac: $31,000 \mathrm{lb}$. sand

IPF: 60 MCFD

Development gas well

Completion date: $2 / 9 / 78$

7. Koch Exploration

1 Cundy

Section 14, T19N, R1E

Harding County, South Dakota

Wildcat

Shannon test $(2,000 \mathrm{ft}$.)

New field wildcat

Status: On location 


\subsubsection{Northern Area}

Drilling activity in the northern area ranges from the Sweetgrass Arch, Toole County, Montana to the west flank of Bowdoin Dome, Valley County, Montana. It involves principally the activity in Toole, Hill, Chouteau, Blaine, Phillips and Valley Counties. Wells of interest to the WGSP are listed in Table 2-1 and located on Figure 2- 3.

During this quarter, there has been a noticeable increase in interest concerning the northwest section of the basin. A greater number of operators testing the Bow Island and 2nd White Specks units (Phillips) in parts of Toole, Pondera and Liberty Counties have generated this new interest. The major operators in the area are Antares Oil, Sun Oil, Montana Power, Fulton Producing, Webb Resources, Western Natural Gas and Milan R. Ayers. Thus far the production has been from the untreated Bow Island, but the area is being monitored for the possibility of future fracture treatments and the subsequent application to the WGSP.

The counties east of the Bow Island exploration, Hill, Blaine, Phillips and Valley, comprise the bulk of drilling and testing activity of interest to the WGSP for the entire province. Prospective shallow gas horizons encompass the entire Upper Cretaceous Sequence over most of the area: Judith River, Eagle, Niobrara, Carlile/Bowdoin and Greenhorn/Phillips sandstones and siltstones.

The Tiger Ridge Field, which produces naturally from the Eagle Sands, is located on the eastern border of Hill County. Tricentrol United States is active in the field and has five tests scheduled to the Eagle. J. Burns Brown has three Eagle tests northeast of the Tricentrol wells in an unnamed field (Well No. 1). Also of importance are the 2nd white Specks tests by Oil Resources and Polumbus Petroleum in the northern most area of the county (Well No. 2). Xeno also has planned a drilling program in the northeastern section of the county. They will be testing the lst and 2nd White Specks and several Eagle zones during the summer.

Blaine County has had noticeably increased drilling activity throughout the quarter. Xeno Inc. has announced plans for 25 to 30 Eagle tests in the Battle Creek Field after entering into a contract with Montana Power to produce and deliver gas for their Box Elder storage unit near Havre. These wells will be monitored for fracture treatments and possible application to the WGSP. John J. Lyon recently completed a well northeast of the Xeno exploratory area, producing 69 MCFD from the treated Eagle (Well No. 3). Other operators in the county with numerous scheduled tests are Fuel Resources Development in Leroy Field, Tricentrol United SLates in Sherard and Tiqer Ridge Fields, and Kissinger Petroleum in Sawtooth Mountain Field.

Chouteau County has most of its exploratory activity focused in the northeast sector, around the Bullwacker Field where production is from the Eagle 
and Carlile zones. Montana Power has a sand fractured well north of Bullwacker Field producing from the Carlile. The IPF is not yet available. J. Burns Brown has previously been active in this area, having completed about five wells producing from the Eagle and has now staked another 2,000 ft Eagle test in an unnamed field (Well No. 4).

An increase in production figures for the North Bowdoin Field, Phillips County has been evidencer during thr quarter. Shenauludh uil corporation has drilled seven gas wells and participated in an eighth completion in the Loring Unit. The wells are presently shut-in awaiting a pipeline connection expected by mid-summer. The productive zones in the eight completed wells are the Bowdoin and Phillips sands. The average rate of flow was 2,211 MCFD (Well No. 5). Just west of the Loring Gas Field in an unnamed field, Midlands Gas Company has completed a 1,700 ft Phillips test with an IP of 769 MCFD from comminyled Bowdoin and Phillips sands. A sand fracture treatment was ulilized.

\subsubsection{Southern Area}

South of the 470 latitude line, the fields are generally smaller, except for those in the Cedar Creek Anticline area of Fallon County. Cedar Creek and Plevna Fields produce from the Judith River and Eagle Formations. Pacer Resources has two wells producing from the treated Judith River/ Eagle in Cedar Creek (Well No, 6).

West of Cedar Creek, Custer and Powder River Counties have had Eagle (Shannon) production at Liscom Creek and Pumpkin Creck Fields. There has been no new drilling in either of these two fields. Petroquest, however, has been active in the area and has recently tested the Shannon, but the well was dry and abandoned (D\&A). Gary operating is also actively exploring the area and has three Muddy tests staked in Bell Creek Field, Powder River County. A most importanl development in South Dakota's Harding County is the staking of a 2,000 ft Shannon test, 16 miles north and a little west of the West Short Pine Hills Field by Koch Exploration (Well No. 7). According to the most recent sources, this wcll was pluyged. Jerry McCutchin has scheduled five new wells in the vicinity of his discovery, which flowed 980 MCFD from the Shannon and opened this South Dakota field. A lease sale will be held in early April at which 158 tracts comprising 57,133 acres are being offered. About half of these tracts are in the vicinity of the 1977 Shannon gas strike at West Short Pine Hills Field.

An interesting development, outside the Basin boundaries, is the possible initiation of a program to evaluate the gas potential in the central crazy Mountain Basin. The project has been in the formative stage for almost four years, however, work may begin in the next few months. The operators, Chevron Oil and Coastal states las, believe gas may be trapped in the Frontier Formation in the vicinity of the volcanic rocks. The Peay and Big Elk (Mowry) sands will be primary objectives. 


\section{GREATER GREEN RIVER BASIN}

\subsection{Core Program}

There has been a significant amount of work accomplished by the USGS in the Greater Green River Basin of western Wyoming on "tight gas sands." The entire basin (see Figure 3-1) has a large amount of section with gas potential in the Upper Cretaceous and Tertiary rocks. However, based on current USGS evaluations, there are selected areas (listed below) that contain a large amount of tight, but essentially, untested section which should be the primary study areas in the Greater Green River Basin for the Western Tight Gas Sands Core Program.

1. The crest of the Wamsutter Arch in Sweetwater and Carbon Counties, the northern edge of which borders on the Red Desert Basin and the southern edge occupies part of the Washakie Basin, TI7N to T2IN, and R9IW to R26W. The section below the commercial Almond and Ericson (Mesaverde) is of pirmary interest in this area.

2. The area east of the Big Piney/LaBarge Field in Sweetwater and Sublette Counties, running north and south through the Pinedale area and to the northern edge of the Green River Basin. These areas skirt the edge of the Wind River Range. Production here is primarily Frontier, with some Mesaverde and Ft. Union tests.

This large area has been broken down into four areas. The specific locations are:
a. West of RIO4W to RlO9W and from $T 22 \mathrm{~N}$, north to $\mathrm{T} 28 \mathrm{~N}$
b. RI06W to RIIIW and from T27N to T3IN
c. Rl08W to Rl12W but not including development drilling, and $\mathrm{T} 30 \mathrm{~N}$ to $\mathrm{T} 35 \mathrm{~N}$
d. North edge of Green River Basin; north into the Hoback Basin, T36N to $39 \mathrm{~N}$ and Rl12W to $114 \mathrm{~W}$.

\subsection{Basin Activity}

During January, February and March, Sweetwater County, Wyoming (the largest county in the Greater Green River Basin) had the majority of drilling and testing operations. Surrounding Sweetwater County, there is important activity located in the Figure Four Canyon and Tip Top Fields of Sublette County, the western edge of Carbon County, the eastern portion of Lincoln 


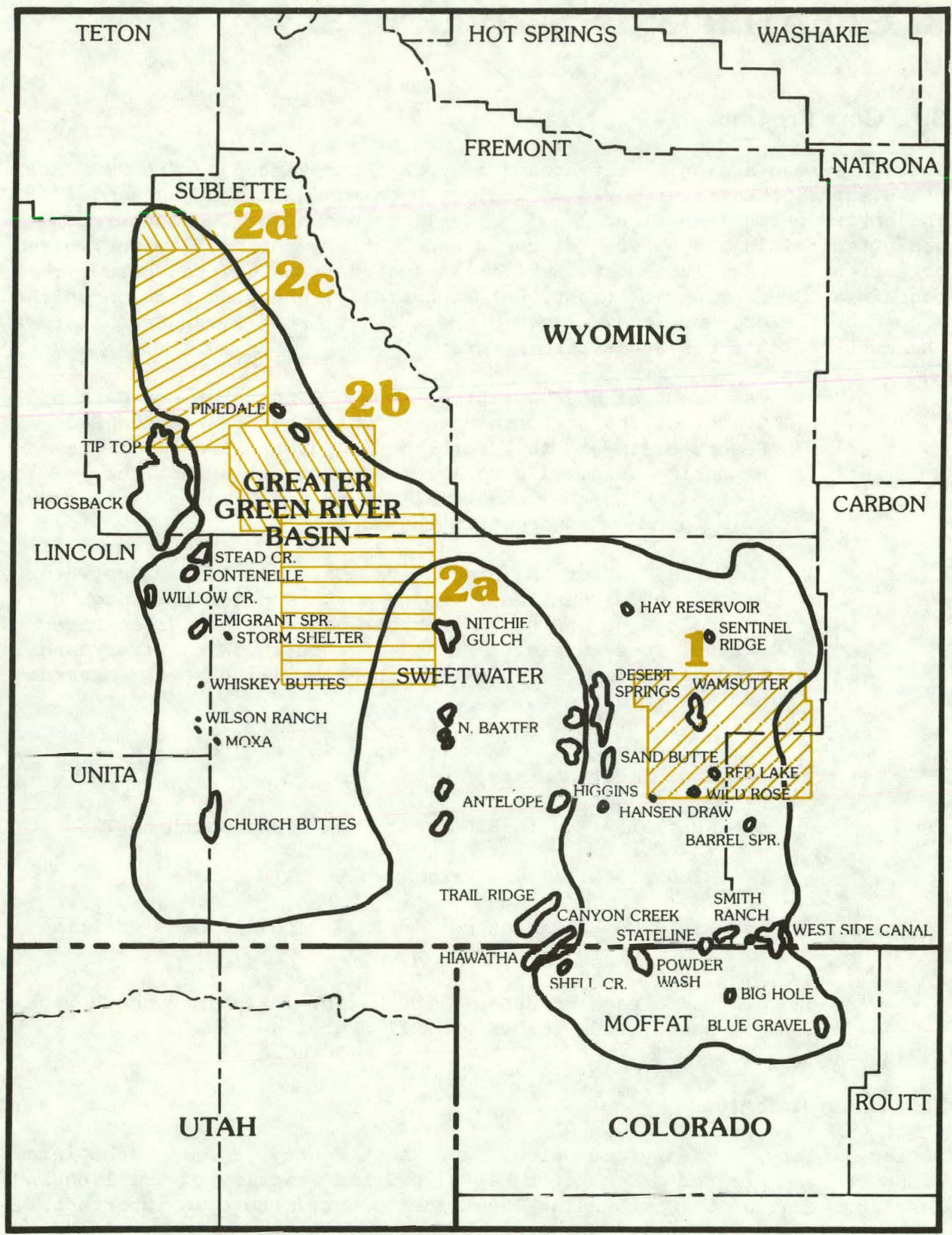

FIGURE 3-1 USGS DESIGNATED CORE AREAS, GREATER GREEN RIVER BASIN 
County and the northern area of Moffat County, Colorado, referred to as the Sand Wash sub-Basin. Refer to Figure 3-2 for the location of wells referred to throughout the text and to Table 3-1 for the corresponding well information.

Objectives in Sweetwater County are the specific formations of the Mesaverde Group, i.e. the Almond, Ericson, Rock springs and Blair. Operators with Mesaverde completions include Smokey Oil and Champlin Petroleum Company both in the Wamsutter areas (Well No. 1), Amoco Production with an apparent discovery in the Hansen Draw Field area (Well No. 2), and CIG with a well flowing 789 MCFD in an unnamed field, northwest of the stateline Field (Well No. 3). This is significant due to the thickness of tight gas section in the area, especially on the north and south flanks of the Wamsutter Arch. There are approximately 20 new Mesaverde tests ongoing in this locale with Amoco Production and Equity Oil Company the major operators.

The Rock Springs Uplift, located in the center of Sweetwater County has been the site of deeper tests into the Frontier and Dakota Formations. The uplift which geographically divides the Green River Basin into the Washakie and Bridger Basin has had gas production since 1922 at the South Baxter Basin Field. This discovery was followed by a Dakota play in the North Baxter Basin.

Major operators in this area are Amoco, Davis and Kenneth Luff, who has completed three wells in the Nitchie Gulch and Crooked Canyon Gas Fields. These wells are producing from the Dakota after a sand-emulsion fracture (Well No. 4). Just south of these completions, Northwest Exploration has a well with an IP of 237 MCFD from the 3 rd Frontier, using a sand-water fracture treatment. Davis Oil Company has staked a location south of the Luff wells in Crooked Canyon to test the Dakota and Jerry Chambers has three Frontier tests in the Potter Mountain Field (Well No. 5)

Carbon, Sublette and Lincoln Counties all have a significant number of Upper Cretaceous tests ongoing of interest to the WGSP. The Mesaverde is the primary objective in Carbon County and the Frontier is most often tested in Lincoln and Sublette Counties. Amoco Production, Marathon Oil, Davis Company, Pacific Transmission Supply, Rainbow Resources and Belco Petroleum are some of the major operators in this very large area.

The western edge of Carbon County has been very productive during this quarter. Michigan-Wisconsin Pipeline is producing 1,043 MCFD from the Mesaverde, a well originally slated to test the Steele Formation (Well No. 6). William Moss Properties has a well within the USGS core site area No. 1 (Figure 3-1) that is an apparent Mesaverde producer; gas flowed at 501 MCFD during a drill stem test. Tom Brown and Sinclair are also quite active in the area Lestiny Llie Mesaverde.

Sublette and Lincoln Counties currently have many ongoing tests in the Frontier and Bear River Formations. Apache Corporation recently completed a well with commingled Bear River/Frontier production in the Figure Four 


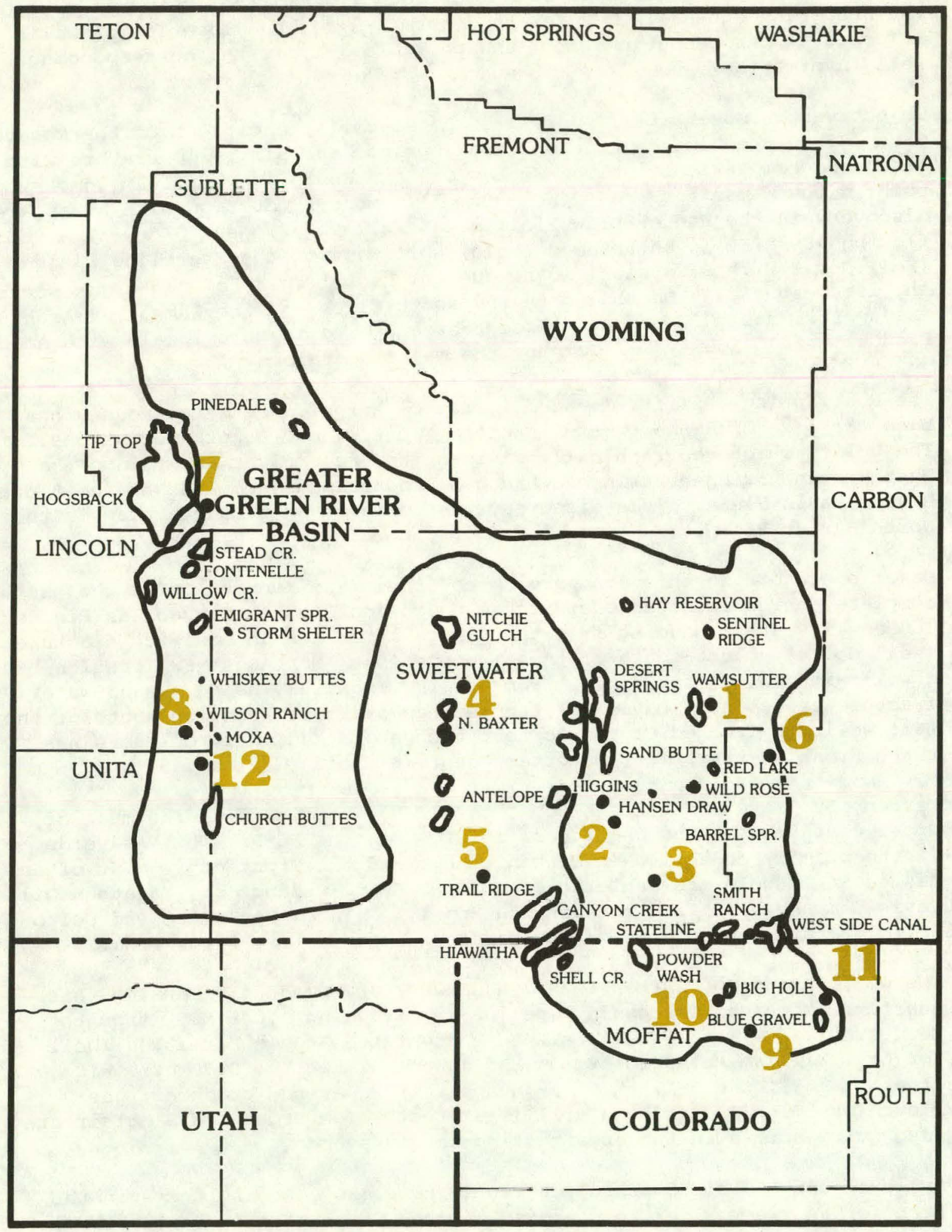

FIGURE 3-2 GREATER GREEN RIVER BASIN SHOWING WELLS OF INTEREST 
TABLE 3-1 INFORMATION ON WELLS IN THE GREATER GREEN RIVER BASIN

1. Champlin Petroleum

5 UPRR $1-7$

Section 7, T20N, R94W

Sweetwater County, Wyoming

Wamsutter Field

Mesaverde Production (9,670-9,690 ft.)

Frac: 88,830 gal emulsion, $112,700 \mathrm{lbs}$. sand

IPF: 2,700 MCFD, $10 \mathrm{BCPD}$

Completion date: $3 / 23 / 78$

Development gas well
2. Amoco Production

535 Amoco A

Section 17, T16N, R97W

Sweetwater County, Wyoming

Wildcat

Mesaverde test $(14,200 \mathrm{ft}$.)

New field wildcat

Status: Testing
3. CIG Exploration Company

1-28 Haystack Unit

Section 28, T14N, R96W

Sweetwater County, Wyoming

Unnamed Field

Mesaverde Production (15,457-16,148 ft. gross)

Frac: 12,028 gal emulsion, $620,000 \mathrm{lb}$. sand

IPF: 789 MCFD

Completion date: $3 / 23 / 78$

Mesaverde discovery-New field

5. Jerry Chambers-Oil Producer

1-15 Kemmerer-Federal

Section 14, T14N, R102W

Sweetwater County, Wyoming

Potter Mountain Field

Frontier test $(8,500 \mathrm{ft}$.)

Development

Status: On location
4. Kenneth Luff

2-17 Amoco-Champlin

Section 17, T21N, R103W

Sweetwater County, Wyoming

Crooked Canyon Field

Dakota Production (5,480-5,485 ft.)

Frac: $22,000 \mathrm{lb}$. sand plus acid

IPF: 700 MCFD

Completion date: $3 / 23 / 78$

Development gas well
6. Michigan-Wisconsin Pipeline

1-27 Creston-Nose

Section 27, T18N, R92W

Carbon County, Wyoming

Unnamed Field

Mesaverde Production (7,788-7,828 ft. gross)

Frac: 20,000 gal. water, $22,000 \mathrm{lb}$. sand

IPF: 1,043 MCFD

Completion date: $3 / 16 / 78$
7. Apache Corporation

\section{2-23 Federal}

Section 23, T27N, R112W

Sublette County, Wyoming

Figure Four Canyon Field

Frontier (7,773-8,021 ft.), Bear River (8,475$8,628 \mathrm{ft}$.) Production

Frac: 195,510 gal emulsion, $95,200 \mathrm{lb}$. sand IPF: 2,830 MCFD

Completion date: $3 / 30 / 78$

Development gas well
8. Mountain Fuel Supply

36-1 State Land

Section 36, T19N, R113W

Lincoln County, Wyoming

Wildcat

2nd Frontier Production (11,367-11,381 ft.)

Trac: $208,000 \mathrm{gal}$ acid, $354,000 \mathrm{lb}$. sand

IPF: 2,674 MCFD

Completion date: $3 / 16 / 78$

Development gas well 


\section{TABLE 3-1 (CONTINUED).}

9. Northwest Exploration

1 Weaver

Section 4, T9N, R93W

Moffat County, Colorado

Wildcat

Lewis Production (7,306-7,541 ft. gross)

Frac: $75,480 \mathrm{gal}$ emulsion, $160,000 \mathrm{lb}$. sand) IPF: 2,300 MCFD

Completion date: $2 / 16 / 78$

New field wildcat
10. Kemmerer Coal

13-1 Federal

Section 13, T10N, R94W

Moffat County, Colorado

Big Hole Field

Lewis Production (7,544-8,881 ft. gross)

Mesaverde Production (8,897-10,154 ft. gross)

Frac: $63,000 \mathrm{gal}$ oil, $554,000 \mathrm{lb}$. sand IPF: 1,287 MCFD

Completion date: $2 / 23 / 78$

Dual complction-Development gàs well

11. Anadarko Production

1-27 Villard

Section 27, T10N, R90W

Moffat County, Colorado

Wildcat

Lewis Production (4,657-4,800 ft. gross)

Frac: $67,000 \mathrm{lb}$. sand

IPF: 2,087 MCFD

Completion date: $3 / 16 / 78$

Development Gas Well
12. Phillips Petroleum

1 Bruff-A

Section 18, T18N, R112W

Uintah Couny, Wyoming

Bruff Field

Frontier Production (11,582-11,622 ft. gross)

Frac: $376,669 \mathrm{gal}$ emulsion, $634,000 \mathrm{lb}$. sand IPF: 639 MCFD

Completion date: $3 / 9 / 78$

Wildcat outpost extension 
Canyon Field (Well No. 7) and Mountain Fuel Supply has a well producing 2,674 MCFD from the Frontier, near Wilson Ranch Field, Lincoln County (Well No. 8).

The southern most portion of the Basin; the Sand Wash sub-Basin in Moffat County, Colorado, has had an increase in the number of completions throughout the quarter. Rainbow Resources and Northwest Exploration have wells producing from the Lewis Formation. The Northwest Exploration well was sand-emulsion fractured (Well No. 9). Kemmerer Coal Company has a dual completion in the Lewis and Mesaverde section, flowing 1,287 MCFD after an oil and sand fracture treatment (Well No. 10). Anadarko Production has also been active in exploration of the Lewis Sands, and has a well producing northeast of the Blue Gravel Field (Well No. 11). The company has recently staked another well in the same township and range to test for the Almond.

Uinta County, Wyoming has a limited amount of activity of interest to the WGSP; most tests are in the Frontier and deeper Nugget (Well No. 12). Mountain Fuel Supply has scheduled a well to test the Mowry/Aspen Formation, an upper Lower Cretaceous zone in the same area as the above production. 
THIS PAGE

\section{WAS INTENTIONALLY \\ LEFT BLANK}




\section{UINTA BASIN}

\subsection{Core Program}

The boundaries of the Uinta Basin (see Figure 4-1) enclose a large area of northeastern Utah with potential "tight gas sand" production. The potentially productive rocks range in age from Upper Cretaceous to Tertiary. Examples of Cretaceous rocks are the Price River, Castlegate, Blackhawk, Sego, Neslen, and Farrer. The Tuscher, Wasatch, North Horn and the Green River are examples of Tertiary rocks. The USGS has recently outlined specific areas of this basin for the acquisition of core in the WGSP core program. These areas, listed below, have limited core data from the potentially productive sections of interest.

1. Wasatch and Duchesne Counties - T4S to T7S, R5W to RIlW; in Wasatch County, T9S to TllS, R7, 8 and 9E; in Carbon County, TIlS to TI2S, R7E to RI3E.

2. Duchesne and Uintah Counties - T3S to T4S, R2E to R2W and parts of T8S, R16E to Rl8E.

3. Uintah County - T8S and T9S and R23, 24 and 25E.

4. Uintah and Grand Counties - TlOS, R18E; Tl1S to T16S, R18E to R25E; and in TI7S, T18S, and T19S, R21E and R22E.

These areas are outside the productive fields of the Uinta Basin, of which the most activity is in the Natural Buttes and Red Wash Fields where production is primarily from the Wasatch, Mesaverde and Green River Formations.

These areas will be closely monitored and operators active in an area of interest will be contacted for possible cost-sharing coring contracts.

\subsection{Basin Activity}

There is limited activity in the Uinta Basin with most drilling and testing concentrated west of the Chapita Wells Gas Field. Refer to Figure 4-2 for well locations mentioned in the text and Table 4-1 for the corresponding well information. During this quarter, the field has had seven wells go on production with an average flow rate of 1,050 MCFD. The operators involved in the area are Belco Petroleum, Gas Producing Enterprises (GPE) and CIG Exploration. Production is from the tight wasatch and Mesaverde units at depths from 5,000 to 9,000 ft. The wells were sand-emulsion fractured, typically with $130,000 \mathrm{gal}$ of emulsion and 255,000 $1 \mathrm{~b}$ of sand (Well No. 1). 


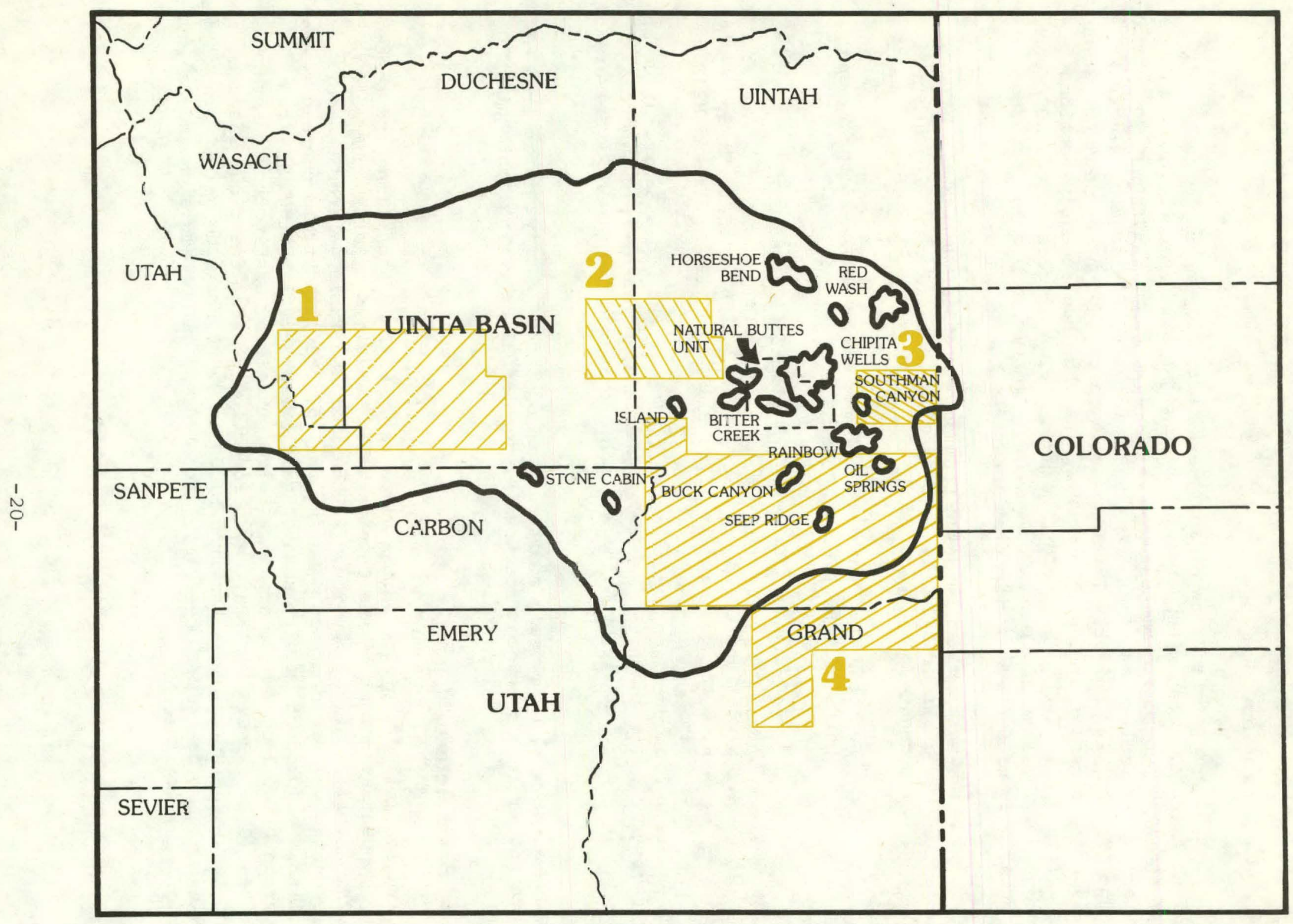

FIGURE 4-1 USGS DESIGNATED CORE AREAS, UINTA BASIN 


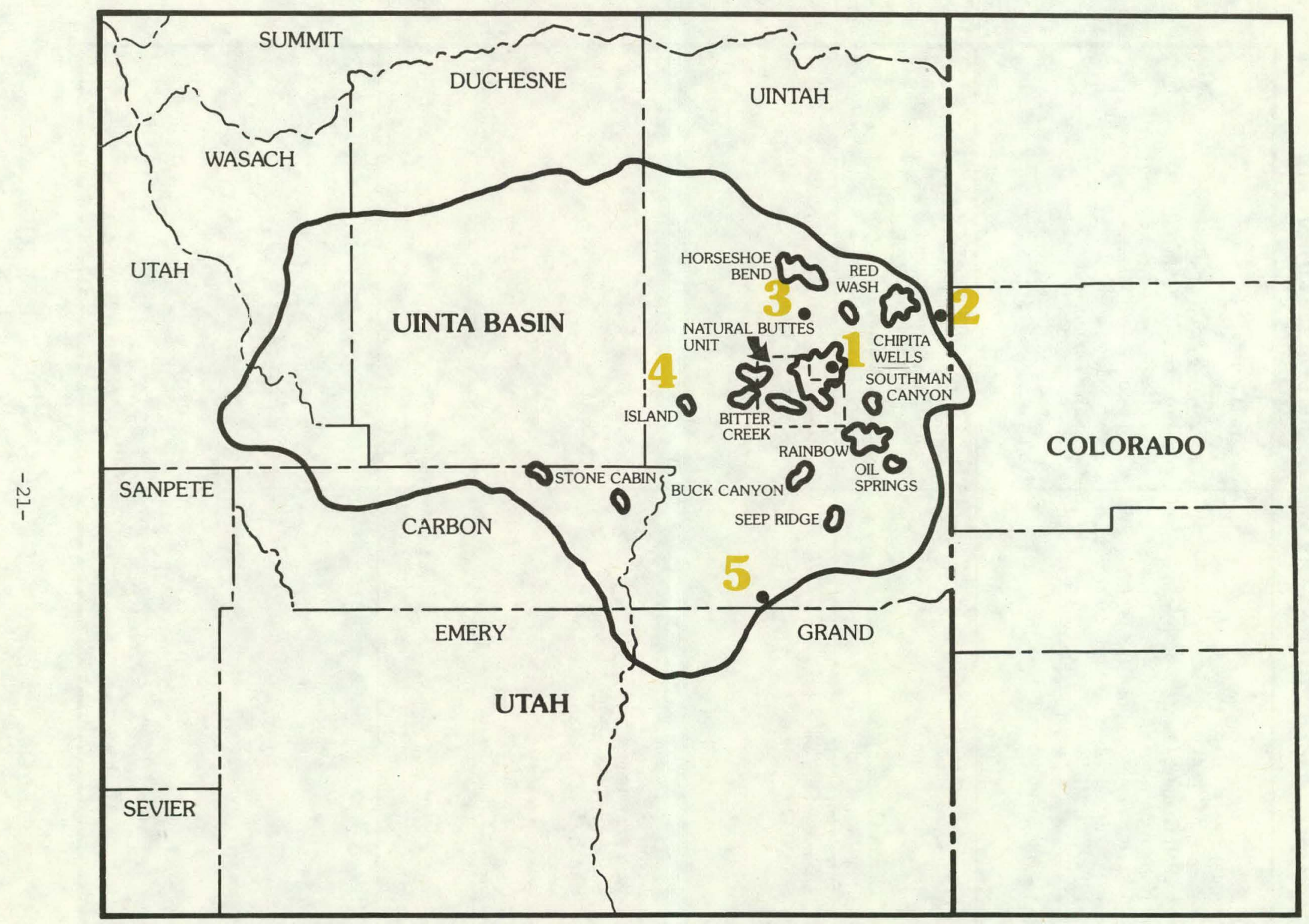

FIGURE 4-2 UINTA BASIN SHOWING WELLS OF INTEREST 


\section{TABLE 4-1 INFORMATION ON WELLS IN THE UINTA BASIN}

1. Belco Petroleum 32-21 Chapita Wells Unit Section 21, T9S, R22E Uintah County, Utah Natural Buttes Field

Wasatch Production $(5,470-6,388 \mathrm{ft}$.)

Frac: 119,000 gal emulsion, $132,000 \mathrm{lb}$. sand IPF: 1,270 MCFD

Completion date: $1 / 5 / 78$

Development gas well
2. Twin Arrow

1 State

Section 2, T7S, R25E

Uintah County, Utah

Wildcat

Mancos test (2,700 test)

New field wildcat

Status: On location
3 Filf Nil C.nmpany 1, 2, and 3 Uinta Tests Section 16, T8S, R21E Uintah County, Utah Red Wash Field Three Uinta tests $(1,750 \mathrm{ft}$.) Shallower pool wildcat Status: On location
4 Manen Incorporated 11-13E Riverbend Unit Section 13, T10S, R19E Uintah County, Utah Island Field Mesaverde test $(8,500 \mathrm{ft}$.) Projected development well Status: On location

5. Exxon U.S.A.

Wolt Yoint Unit

Section 2, T15S, R21E

Uintah County, Utah

Wildcat

Wasatch test $(10,500 \mathrm{ft}$.)

New field wildcat

Status: On location 
Surrounding this productive area, exploratory activity is taking place in other parts of Uintah County; especially in the northeastern region. Twin Arrow has a location (Well No. 2) for a 2,700 ft Mancos test, about 1-1/2 mile west-northwest of the Dinosaur Field, Moffat County, Colorado. A little southwest of this activity, Gulf Oil has three Uinta (Tertiary) tests staked (Well No. 3). The location is nine to ten miles southwest of the shut in Horseshoe Bend Gas Field, which is capable of producing from the Uinta. Two miles west of East Gusher Field, Teton Energy has scheduled three Mesaverde tests in Island Field. Belco Petroleum is also actively testing the Mesaverde in this area (Well No. 4). The wells in the region are being fractured with sand-emulsion treatments. Exxon has a well scheduled to test the lower Wasatch $(10,500 \mathrm{ft})$ in the southern portion of the Basin (Well No. 5).

Other counties within the Basin boundaries are parts of Duchesne, Carbon, Wasatch, and the Segundo Canyon Field area of Grand County. Activity of relevance to the WGSP in these counties is very limited.

Duchesne County has activity focused in the Altamont and Bluebell Fields, where production is from the deep Wasatch $(10,000-17,000 \mathrm{ft})$ and consists mostly of oil with associated gas. The Peter's Point Field, Carbon County, produces from the Wasatch, however, Reserve Oil recently completed a test in the area which was D\&A. The Segundo Canyon area, the southern most region of the basin is being monitored for possible core sites (Figure 4-1). Anschutz Corporation is most active in the locale and is testing the Mancos, Entrada and Morrison Formations.

An article written by J.A. Short, Northern Regional Production Manager for GPE appeared in The Oil and Gas Journal, dated January 16, 1978. The paper presented the results of GPE's MHF stimulation of the low permeability Wasatch and Mesaverde Sands. GPE's wells have been much more successful than earlier conventional completions., which generally resulted in uneconomic production. 


\section{THIS PAGE \\ WAS INTENTIONALLY \\ LEFT BLANK}




\section{PICEANCE BASIN}

\subsection{Core Program}

The Piceance Basin of northwestern Colorado (see Figure 5-1) has a large amount of tight Upper Cretaceous and Tertiary gas sands, such as Castlegate, Sego, Corcoran, Cozzette, Iles, Williams Fork, Ft. Union and Wasatch Formations. Some of these units are producing gas in very active fields such as Cathedral, Piceance Creek, Trail Canyon, Thunder, Dragon Trail and Texas Mountain. However, outside of these fields, very little information is available on these units due to a limited amount of drilling activity. For instance, in the Piceance Creek Field, there is also interest in, but little data on, rocks below the commercial Wasatch. This becomes even more evident when attempting to find suitable core data for these rocks. The USGS has indicated key areas in the Piceance Basin with a significant amount of "tight gas" sections but limited control. These areas will be used initially to acquire the needed information specified by the WGSP Core Program. The following is a list of these areas:

1. East of Rangely Field in Rio Blanco County, TIS to T2N, R98W to R99W.

2. Piceance Creek Field area, Rio Blanco County, T2S, R96W to R97W.

3. Garfield and Mesa Counties, T5S to T8S, R95W to R99W in the north tapering down to R98W to R99W on the southern part of the area.

4. Garfield and Mesa Counties, T8S to T10S, R92W to R94W (this area is flanked on the northwest and southeast by the Grand Mesa National Forest).

Operators active in these areas will be contacted for possible participation in DOE's core program.

\subsection{Basin Activity}

Drilling and testing activity in the Piceance Basin has been on a steady increase since the first of the year. There were 126 "active" wells listed by one industry news reporting company at the beginning of January. At month's end, the same publication listed 148 wells as active, uncompleted or on holding status. Major objectives are the Mancos and Wasatch Formation in Rio Blanco County, the Mesaverde and Cozzette/Corcoran in Mesa County and the Dakota/Morrison in the Douglas Creek Arch, Garfield County. 


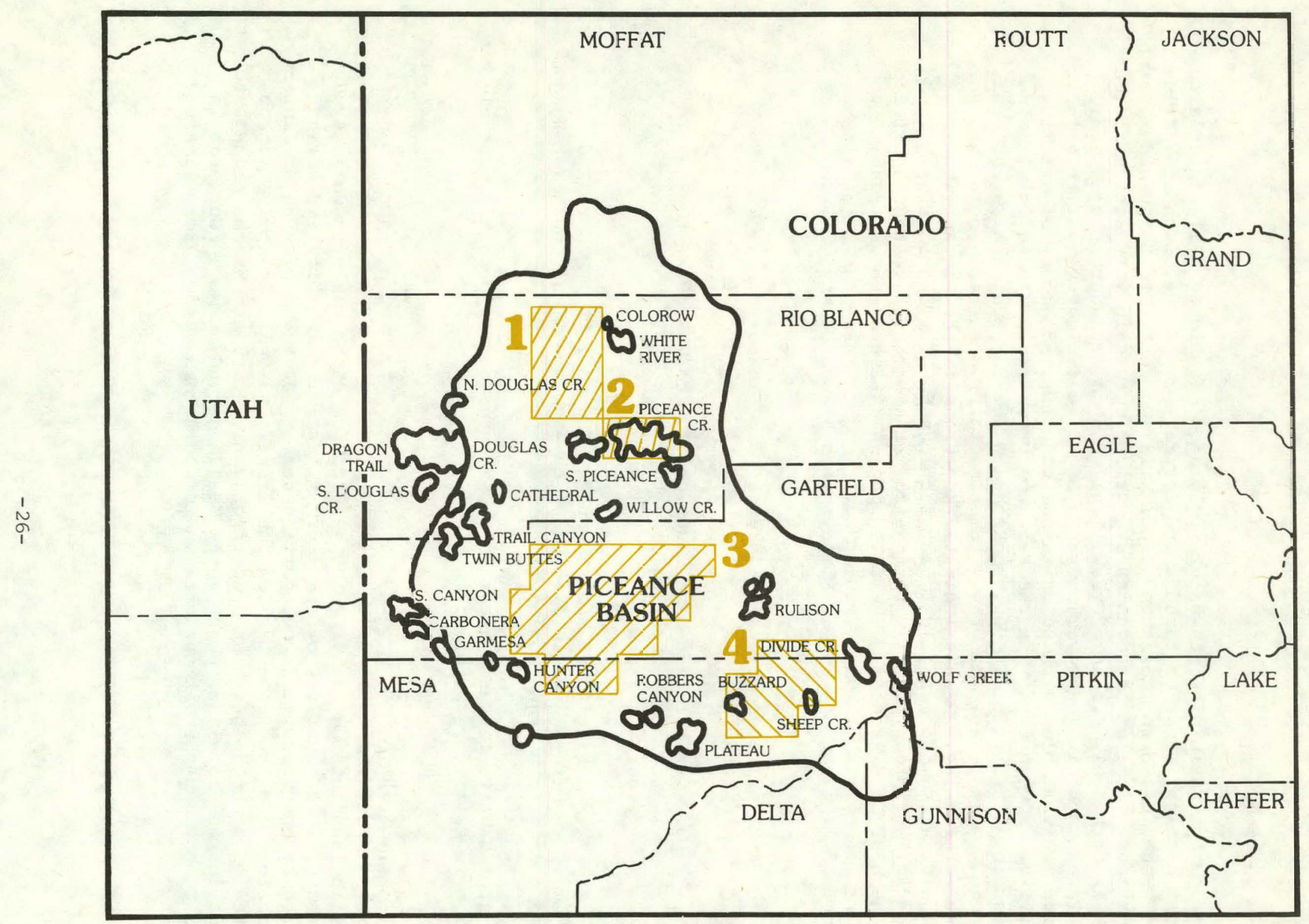

FIGURE 5-1 USGS DESIGNATED CORE AREAS, PICEANCE BASIN 
Rio Blanco County is the most active area in the basin. Refer to Figure 5-2 for the location of wells mentioned in the text and Table 3-1 for the corresponding well information. The Lower Horse Draw, Trail Canyon and Cathedral Fields all have had increased drilling activity. Production in these areas has been from the Mancos and Mancos "B" zones. Joseph B. Gould currently has seven tests scheduled in the Lower Horse Draw area, and American Resources Management is active in the Trail Canyon Field. Operators in Cathedral Field include Northwest Exploration, Fuel Resources Development, Mountain Fuel Supply, Twin Arrow and Chandler \& Associates.

There is new interest in the central area of Rio Blanco County, specifically in the Piceance Creek Field. This is due to the staking of five new locations by Indian Wells Oil and eight locations by Mobil (Well No. 1). All thirteen new locations are projected to the Wasatch. These wells will be monitored closely for possible frac treatments and evaluated for application in the WGSP.

In the very productive Plateau Field, Mesa County, Mountain Fuel Supply has a well producing from the Corcoran Sand (Well No. 2). Adolph Coors has five tests slated in the area with probable objectives in the Rollins, Cozzette, and Corcoran sandstones (Well No. 3). Teton Energy also has a test in the vicinity projected to the Morrison beds (deeper Cretaceous) in Coon Hollow Field (Well No. 4).

A completion of interest to the WGSP was reported January 26, 1978 by David M. Munson in Divide Creek Field, Garfield, County, Colorado. Mesaverde gas production was established after a frac using 65,000 gal of emulsion and $132,000 \mathrm{lb}$ of sand (Well No. 5). It is also interesting to note the increase in production on the Douglas Creek Arch, Garfield County. Operators with producing wells are Polumbus Company in the Prairie Canyon Field, Palmer Oil and Gas Company in South Canyon and Bridle Fields and Texas Gas Exploration also in Bridle Field. All wells in the area are producing from the Dakota/Morrison, Dakota/Salt Wash, or Dakota/Cedar Mountain. Seven completed wells in the area produced a total of 7,633 MCFD during the month of March; the average IP was 1,090 MCFD. Palmer Oil and Gas has eleven locations in this area and all are projected to the Morrison Formation (Well No. 6). 


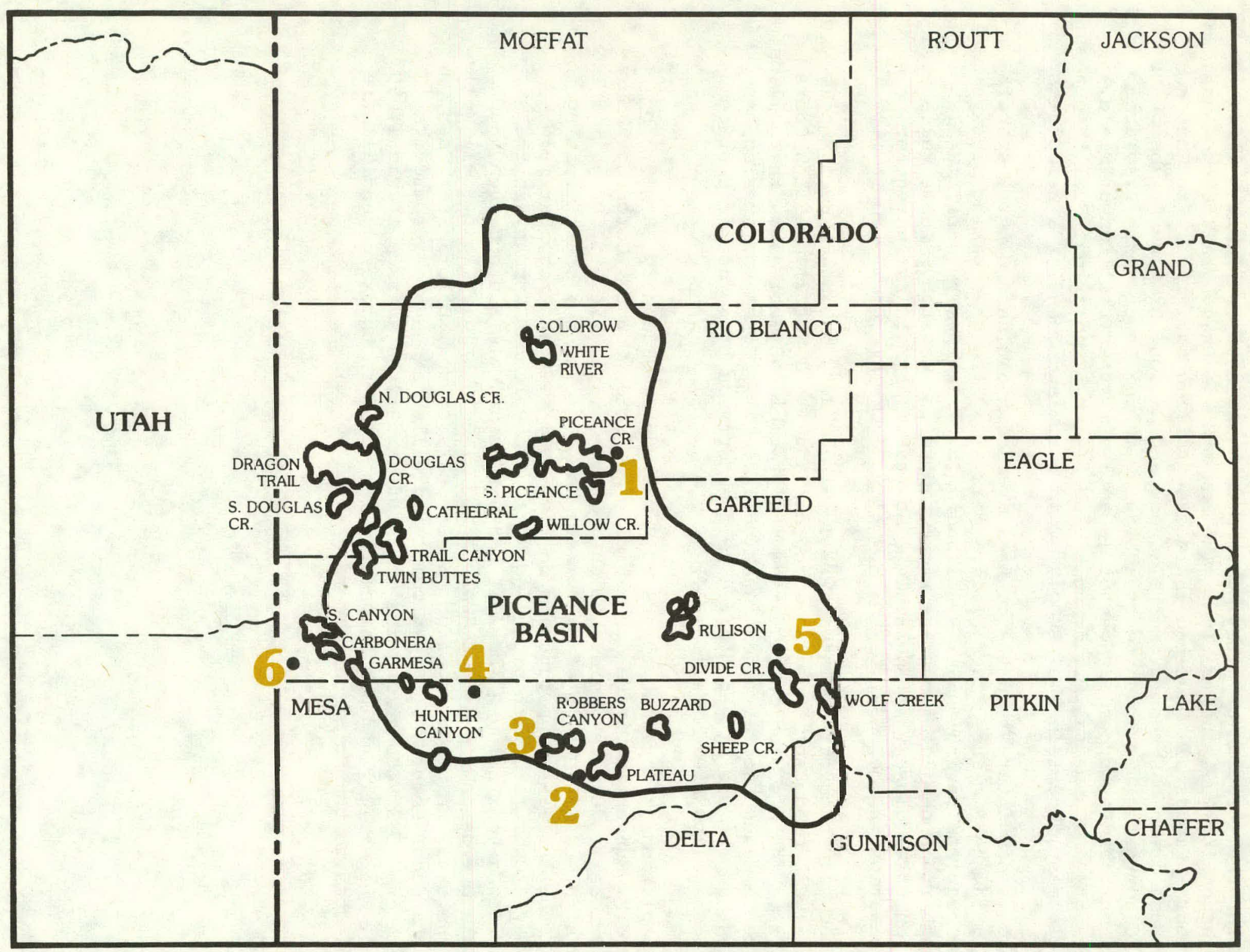

FIGURE 5-2 PICEANCE BASIN SHOWING WELLS OF INTEREST 


\section{TABLE 5-1 INFORMATION ON WELLS IN THE PICEANCE BASIN}

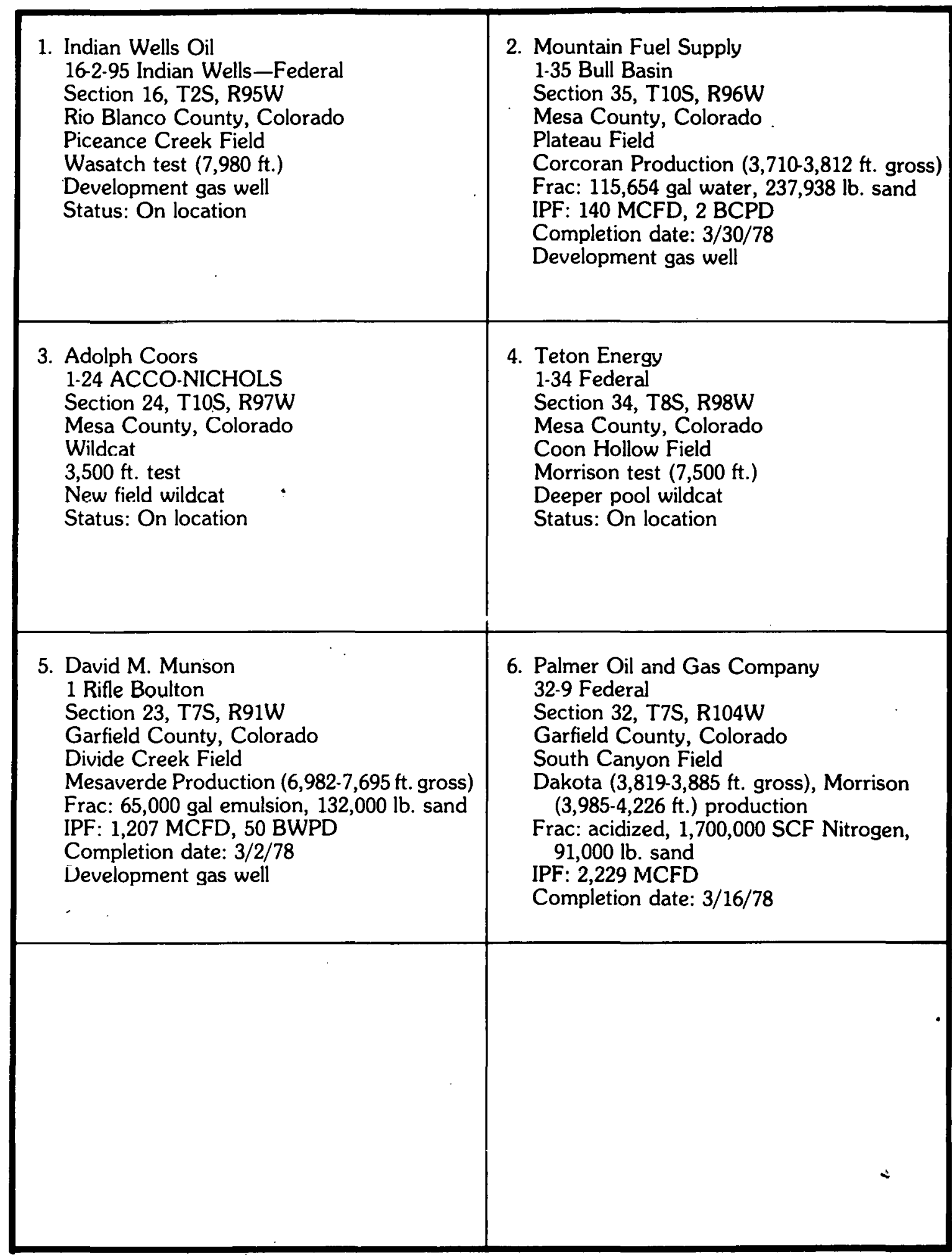

